Portland State University

PDXScholar

Engineering and Technology Management

Faculty Publications and Presentations

\title{
Theoretical Framework for Managing the Front End of Innovation under Uncertainty
}

Antonie J. Jetter

Portland State University, ajetter@pdx.edu

Richard Sperry

Portland State University

Follow this and additional works at: https://pdxscholar.library.pdx.edu/etm_fac

Part of the Engineering Commons

Let us know how access to this document benefits you.

\section{Citation Details}

Sperry, Richard; Jetter, Antonie J.: Theoretical Framework for Managing the Front End of Innovation under Uncertainty, Proceedings of PICMET 2009: Technology Management in the Age of Fundamental Change, pp. 2021-2028, August 2-6, 2009, Portland, OR

This Article is brought to you for free and open access. It has been accepted for inclusion in Engineering and Technology Management Faculty Publications and Presentations by an authorized administrator of PDXScholar. Please contact us if we can make this document more accessible: pdxscholar@pdx.edu. 


\title{
Theoretical Framework for Managing the Front End of Innovation under Uncertainty
}

\author{
Richard Sperry, Antonie Jetter \\ Dept. of Engineering and Technology Management, Portland State University, USA
}

\begin{abstract}
A growing body of research suggests that the fuzzy front-end of product development should not be managed with a one-size-fits-all standard process. Instead, projects with different market and technical uncertainties should be managed with one of five different processes (linear, recursive, evolving, selectionism, trial-and-error). Based on a review of the literature, the paper develops a theoretical framework for frontend management which provides the foundation for ongoing empirical research.
\end{abstract}

\section{INTRODUCTION}

In business and technology, new product development (NPD) is known as the process of bringing new products or services to commercialization. This process is often conceptualized as a funnel which narrows down a large number of product ideas, so that in the end, only winners come out [27]. Picking these winners is all but simple: a PDMA 2004 study on product development performance shows, that of all new product ideas generated, $68 \%$ passed through idea screen, $47 \%$ passed business analysis, 33\% made it to development, $28 \%$ were tested successfully in the market, $24 \%$ were commercialized, and only $14 \%$ resulted in successful products $[1, \mathrm{p} 10]$.

The initial activities of ideation, initial assessment, concept development, and business case analysis are commonly referred to as the fuzzy front-end (FFE) of new product development. In these stages, ideas and product concepts are shaped, and justified before the receive approval to move to full scale development, commonly known as NPD execution [12]. There is an underlying assumption for separating the front-end from NPD execution and managing both phases with distinctly different processes is they each encounter different levels of uncertainty [11-13, 21, 25, 34, $36]$. Since only $33 \%$ of all ideas made it to development, the front-end activities strongly impact overall product development success. It can also be said that new product success is influenced by uncertainties, especially in the early stages of innovation $[2,6,15,18,19,29,33,36]$. As portrayed in

Figure 1, the front-end has higher levels of uncertainty and tend to be more freewheeling; therefore managing these activities requires a process that leaves room for iteration [13]. At the point where the concept crosses into the NPD Execution the plans are defined and the process is more stable; therefore, a linear flow is typically used $[6,9]$.

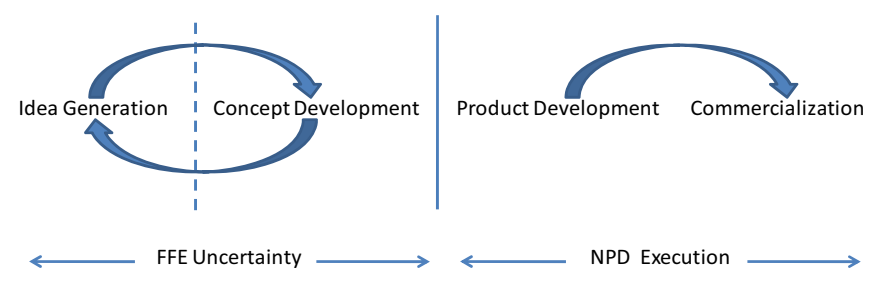

Figure 1: NPD Framework

This approach; however, increasingly questions the funnel described in the above 2004 study for it shows less than $60 \%$ of the carefully selected product ideas that are commercialized are successful [1, p8]. This means there are obviously still a lot of critical uncertainties left in late stages of product development; thereby, suggesting the management of upfront certainties is not effective. The same study furthermore shows that, compared with 1995, more development projects today are incremental with sales and profits also declining [1, p39]. Studies suggest that linear development processes are best suited for incremental development and will not lead to breakthrough products [20]. It is thus possible that the processes employed today mandate only ideas with a justified business case or short-term profit to advance, and thereby suffocate breakthrough innovation in favor of incremental development.

In response to these findings, alternative models for the management of new product development are being discussed in the literature (.e.g., chaotic, recursive) [6, 13, 20]. This paper reviews the state of the art and develops a theoretical framework for managing uncertainty in new product development. It is subsequently organized in three main sections. Section 2 reviews the state of the art and reviews and systemizes existing front-end management approaches (section 2.1.), introduces the concept of uncertainty in product development (section 2.2), and develops a typology of new product development projects according to their stage in the technology adoption cycle(section 2.3). Section 3 integrates these findings by discussing how different types of development projects and their associated uncertainties are best managed. Conclusions and the need for future research are discussed in section 4 .

\section{STATE OF THE ART}

\section{A. Front End Management Process Models}

It has been stated that NPD failures result from not integrating the company's product strategy with a wellplanned product portfolio that is based on clear customer 


\section{PICMET 2009 Proceedings, August 2-6, Portland, Oregon USA @ 2009 PICMET}

needs $[8,12]$. Research stresses the need to screen ideas and insert Go/Kill decisions as a means to improve new product success $[3,7,26]$. Where research varies is how the front end activities are managed. The following analysis characterizes the various management processes by including decision making techniques for advancing ideas and developing the product concept. In all, 17 models are categorized as linear, recursive, evolving, selectionism, and trial-and-error.

Khurana and Rosenthal indicate as new ideas and concepts are created, there reaches a point where the process moves from informal to formal [12]. Khurana and Rosenthal's model focuses on this initial transition and pushes forward a need/concept. Once these phases have been completed the formal concept moves to NPD process execution. Khurana and Rosenthal's stress the importance that businesses need to plan their product portfolio and map all new product initiatives across the business for balancing risk and potential return, while ensuring consistency with the product and business strategy. They call this Pre-Phase Zero: Preliminary Opportunity Identification Market and Technology Analysis. Once aligned, the idea can move linear into Phase Zero: Concept and Definition, Phase One: Product Definition and Project Planning, and then NPD Execution.

Cooper and Kleinschmidt identified nine lessons learned to improve new product success that are centered on customer value, market orientation, technical feasibility, business need, time to market, and disciplined execution [7]. Cooper's well known Stage-Gate TM model is a linear process consisting of five "stages" [8] that moves the product from an idea, through preliminary investigation, business case, development, pilot, and finally to full production and market launch, providing it passes the Go/Kill criteria. Like Khurana and Rosenthal, Cooper et al acknowledge that while a company has implemented a systematic process, it must also have effective Go/Kill decision points and move toward portfolio management that selects high value or profitable projects that are aligned strategically [7]. Each stage consists of cross-functional and parallel activities that must be successfully completed and obtain management approval to proceed to the next stage of product development. At the beginning of each stage there is a "gate" where pre-defined decision criteria are checked. It is at these gates where Go/Kill decisions are made that will either stop or allow the concept to continue onto the next phase.

The 2004 study found that average cycle time for new to the world product was 104 weeks, major revisions were 62 weeks, and incremental development was 29 weeks [1, p13]. Time to market is critical to new product development [7, 9, 21]. Copper et al defined the significant customer request (SCR) and fast track process for lower risk projects [7]. Cunha and Comes also defined a "compression" model that is based it on Cooper's, and Clark's and Wheelwright's suggestion for overlapping steps [9]. Overlapping or "crashing" is a common approach in project management [22]. However, it assumes activities are well planned and known in advance, and uncertainty is reduced as much as possible. Others techniques for compression is to collapse steps by simplifying the planning, eliminating unnecessary steps, involving suppliers among others [7, 9].

Like Khurana and Rosenthal, Koen et al focuses on the front end, but makes it perfectly clear their NCD model is not a process, but rather it consists of five elements of Idea Generation \& Enrichment, Idea Selection, Concept Definition, Opportunity Identification, and Opportunity Analysis [13]. Koen et al state the NCD is a recursive/circular shape that allows ideas to flow, circulate, and iterate amongst all five elements, in any combination or order, as well as one or more elements at once. Two aspects to the NCD model are management's support (engine) and the purpose for free flowing elements is to evolve the idea based on learning. Cunha and Comes describe their rendition of a recursive model as "integrative" because NPD is complex and it needs to obtain, transform, and interpret internal and external information using multiple areas within the company to pool and communicate their knowledge [9]. Cunha and Comes, as well as Koen et al indicate this model moves away from the structured process that transforms input into output, such as a linear or sequential process. The Deft model as described by Buijs acknowledges Koen's et al view that the front end is not orderly and requires teamwork [4]. The Deft model visualizes the process as a circular model suggesting there is no beginning or end, after releasing a new product because of the need to react to competitors as to improve performance. The literature was clear that recursive differentiated from linear in that, idea generation is not single step in a process. It involves multiple disciplines that are influenced by environmental factors and effective screening is only one aspect of the front end [13].

Thomke et al argue relative efficiency of experimentation can be best estimated using "known's" in the solution space and that trial-and error allows learning of new knowledge [30]. Cheng and Van de Ven indicate uncertainty is reduced in the actions and outcomes - positive and negative feedback influenced by exogenous and endogenous sources [6]. Cheng and Van de Ven describe their chaotic model as a process where initial steps exhibit non-linear, non-orderly, nonpredictable, non stochastic process. They further emphasize that in the chaotic model, feedback learning is comprised through a balance between exploration (purpose of discovery) and exploitation (achievement), and when learning is achieved, the chaotic relationships amongst the initial trials begin to stabilize, thereby converging into periodic conditions or orderly. Thomke et al offers two variations to serial experimentation: rapid and minimal learning. Rapid learning is when you repeat a trial in effort to learn more each time, whereas minimal learning is defined as not repeating an experiment that has failed, which supports Cheng and Van de Ven concept of exploration and 


\section{PICMET 2009 Proceedings, August 2-6, Portland, Oregon USA @ 2009 PICMET}

exploitation. When goals are not clear, screening is difficult and it is not sufficient as the primary link between the flows of idea searching and implementation [14].

McCarthy et al argue that NPD teams deal with uncertainty through information [20]. They define a Complex Adaptive System (CAS) as one where decision rules and agents influence the pace of the NPD process through selforganization and emergence. CAS differs from linear models, which McCarthy et al define as structured and tightly coupled. In a CAS model, agents partially connect to and interact with other agents, and the execution of decisions or choice options are controlled by organizational rules and criteria (e.g., formal procedures and checks). Agents are people that learn and adapt based on experimentation and exploration and an agent uses input to make a decision as well as creating output (information) to be used by other agents [5]. Decisions between agents may represent milestones or a decision governed by strategy, while decisions made within the context of the agent are considered operational where customer requirements are assessed or product characteristics are determined [20].

Myer's defines the agile model as a learning-feedback technique that has various flavors, but the common theme is to refine or gain more clarity on requirements that are derived from the real world [24]. Myer indicates agile requires multiple iterations that are time boxed and that teams learn and adapt from feedback, thereby becoming self-organizing. Cunha and Comes support the notion of agile product development with their "flexible" model that keeps concept development open as long as possible to reduce uncertainties [9]. They furthermore indicate this requires frequent iteration and testing. Cunha and Comes also define an "improvisational" model as shifting under fluid conditions by combining the exploratory learning of the flexible model, but use minimal control structures - operate autonomously within the guideline as "big" rules [9]. Dahn and Mendelson indicate that parallel concept testing is a way to search for the "best" design [10]. Thomke et al indicate a range landscapes can be searched by conducting experiments in parallel, thereby increasing efficiency[30]. Sommer and Loch define selectionism as "pursing several approaches independent of one another and picking the best one ex-post [29, p1334].“

TABLE 1 is a summary of the front end processes discussed. From this literature review, five basic processes have been identified. Linear assumes that each step is deterministic and must be completed successfully before moving on the next. There is a slight variation to linear, in that, steps may be eliminated or overlap one another to reduce lifecycle time. However, linear demands well structured and planned activities that use screening between stages. Recursive on the other hand assumes that each of the elements is loosely coupled and is not a process [13]. Integration or movement is achieved is triggered by environmental feedback and feed forward loops. Evolving also uses feedback learning, but fundamentally differs from recursive in that, it starts with some requirement(s) or direction, no matter how vague, and aims to refine or exploit the concept through feedback. Selectionism is a special case in that adapts from learning; however, it does so after generating multiple independent concepts, tests the concepts, and picks the best one ex-post. Trial-and-error is a process where initial steps exhibit non-linear, non-orderly, nonpredictable, non stochastic process. The emphasis on trialand-error is feedback learning but differs from evolving as it may not start with a requirement and it uses a balanced approach between of exploration and exploitation. When the result is positive, it continues the exploitation of the idea until it comes across a negative outcome or it has succeeded. When a negative outcome is reached, it reverts back to exploring other ideas.

\section{TABLE 1: FUZZY FRONT END PROCESSES}

\begin{tabular}{|c|c|c|}
\hline FFE Process & Description & Applicable Models \\
\hline Linear & $\begin{array}{l}\text { Front end steps are relatively } \\
\text { deterministic and tightly } \\
\text { coupled. Each step must be } \\
\text { successfully completed prior to } \\
\text { obtaining management approval } \\
\text { to proceed to the next stage of } \\
\text { product development based on } \\
\text { profitability and strategic } \\
\text { alignment. Steps may overlap } \\
\text { one another to improve } \\
\text { timelines. }\end{array}$ & $\begin{array}{ll}\text { 1. } & \text { Stage Gate } \\
& 28] \\
\text { 2. } & \text { Khurana \& } \\
& \text { Rosenthal's [12] } \\
\text { 3. } & \text { SCR [7] } \\
\text { 4. } & \text { Fast Track [7] } \\
\text { 5. } & \text { Compression [9] }\end{array}$ \\
\hline Recursive & $\begin{array}{l}\text { Front end steps are loosely } \\
\text { coupled with multiple feedbacks } \\
\text { and feed forward loops between } \\
\text { elements that produce an } \\
\text { iterative and integrative type of } \\
\text { behavior. Outcomes from each } \\
\text { step are harder to predict. }\end{array}$ & $\begin{array}{ll}\text { 6. } & \text { NCD [13] } \\
\text { 7. } & \text { Integrative [9] } \\
\text { 8. } & \text { Deft Product } \\
& \text { Innovation [4] }\end{array}$ \\
\hline Evolving & $\begin{array}{l}\text { A process where initial steps } \\
\text { begin with vague requirements. } \\
\text { Emphasis is on feedback } \\
\text { learning for the purpose of } \\
\text { exploiting and refining } \\
\text { direction. Techniques include, } \\
\text { but not limited to, prototyping } \\
\text { or simulation. }\end{array}$ & $\begin{array}{ll}\text { 9. } & \text { Serial } \\
& \begin{array}{l}\text { Experimentation - } \\
\text { rapid learning [30] }\end{array} \\
\text { 10. } & \text { Complex Adaptive } \\
& \text { System [20] } \\
\text { 11. } & \text { Agile [24] } \\
\text { 12. } & \text { Flexible [9] }\end{array}$ \\
\hline Selectionism & $\begin{array}{l}\text { Front end generates multiple } \\
\text { independent concepts for testing } \\
\text { and based on ex-post learning, } \\
\text { the best concept is picked. }\end{array}$ & $\begin{array}{ll}\text { 13. } & \text { Selectionism }[29] \\
\text { 14. } & \text { Parallel }[10,17]\end{array}$ \\
\hline Trial-and-error & $\begin{array}{l}\text { A process where initial steps } \\
\text { exhibit non-linear, non-orderly, } \\
\text { non-predictable, non stochastic } \\
\text { process. Emphasis is on either } \\
\text { trial-and-error. Trial-and-error is } \\
\text { comprised of two dimensions: } \\
\text { exploration (purpose of } \\
\text { discovery) and exploitation } \\
\text { (achievement). }\end{array}$ & $\begin{aligned} \text { 15. } & \text { Serial } \\
& \text { Experimentation - } \\
& \text { minimal learning } \\
& {[30] } \\
16 . & \text { Chaotic [6] } \\
17 . & \text { Improvisational [9] }\end{aligned}$ \\
\hline
\end{tabular}




\section{PICMET 2009 Proceedings, August 2-6, Portland, Oregon USA @ 2009 PICMET}

\section{B. Uncertainty in New Product Development}

Zhang and Doll define uncertainty "as the inability to assign probabilities to outcomes and risk is regarded as the ability to assign such probabilities based on differing perceptions of the existence of orderly relationships and patterns [36, p97]." They indicate three sources of uncertainty: customer requirements, competition and changing technology. Similarly, MacCormack and Verganti differentiate between technical uncertainty about design matters and market uncertainty about customer requirements [19]. Sommer and Loch define foreseeable uncertainty as the "inability to recognize and articulate relevant variables and their functional relationships [29, p1334]." They further indicate uncertainty is influenced by the ability define and articulate factors such as requirements, customer preferences, competitors, resources, technology, and regulations. Krishman and Bhattacharya emphasize that technical uncertainty "is the selection of component technology that offers the product its ability to perform at the level set in its specification [15, p314]." For purposes of this paper, uncertainty will be characterized by the technical and market attributes as defined table 2 and the level uncertainty is defined as high, medium-high, medium, medium-low and low as defined table 3.

TABLE 2: SOURCES OF UNCERTAINTY

\section{Technical}

\section{Market}

\begin{tabular}{|l|l|}
\hline System size or variables & Requirements \\
Number of interactions & Preferences \\
Level of detail knowledge of & Lifecycle \\
specifications and interfaces & Adoption - timing in acceptance \\
Level of performance per & Competitor product offerings \\
specification & \\
Changing technologies & \\
\hline
\end{tabular}

TABLE 3: LEVEL OF UNCERTAINTY

\begin{tabular}{|l|l|l|}
\hline \multicolumn{2}{|c|}{ Level } & \multicolumn{2}{c|}{ Technical } \\
\hline High & $\begin{array}{l}\text { Have very limited or no } \\
\text { knowledge about the product } \\
\text { technologies we ended up using. }\end{array}$ & $\begin{array}{l}\text { Have very limited or no } \\
\text { knowledge about customer } \\
\text { needs }\end{array}$ \\
\hline $\begin{array}{l}\text { Medium- } \\
\text { High }\end{array}$ & $\begin{array}{l}\text { Have some idea about the } \\
\text { technology, but there were many } \\
\text { uncertainties }\end{array}$ & $\begin{array}{l}\text { Have some idea about the } \\
\text { customer needs, but there } \\
\text { were many uncertainties }\end{array}$ \\
\hline Medium & $\begin{array}{l}\text { Have an average understanding } \\
\text { of the technology with a typical } \\
\text { amount of uncertainties }\end{array}$ & $\begin{array}{l}\text { Have an average } \\
\text { understanding of the } \\
\text { customer needs with a } \\
\text { typical amount of } \\
\text { uncertainties }\end{array}$ \\
\hline $\begin{array}{l}\text { Medium- } \\
\text { Low }\end{array}$ & $\begin{array}{l}\text { Have a good understand of the } \\
\text { technology with only few } \\
\text { uncertainties }\end{array}$ & $\begin{array}{l}\text { Have a good understanding } \\
\text { of the customer needs. There } \\
\text { were few uncertainties }\end{array}$ \\
\hline Low & $\begin{array}{l}\text { Have a full understanding of the } \\
\text { technology and there were no } \\
\text { uncertainties }\end{array}$ & $\begin{array}{l}\text { Have a full understanding } \\
\text { of the customer needs and } \\
\text { there were no uncertainties }\end{array}$ \\
\hline
\end{tabular}




\section{PICMET 2009 Proceedings, August 2-6, Portland, Oregon USA @ 2009 PICMET}

the end of the product lifecycle, because products based on the older technology can still be sold.

Table 4 summarizes the typology of new product projects, based on their stage in the S-curve technology life cycle and technology adoption life cycle. This differentiation is important, because different project types are associated with different types of uncertainty [23], which provides a common bridge between the rate of technology performance and market adoption rates as shown in table 5 .

\section{TABLE 4: TECHNOLOGY PERFORMANCE AND ADOPTION} PERIODS

\begin{tabular}{|c|c|c|c|}
\hline $\begin{array}{c}\text { Technology } \\
\text { Performance }\end{array}$ & Description & $\begin{array}{c}\text { Innovation } \\
\text { Project Category }\end{array}$ & $\begin{array}{l}\text { Marketing } \\
\text { Adoption }\end{array}$ \\
\hline $\begin{array}{l}\text { Technology } \\
\text { Invention }\end{array}$ & $\begin{array}{l}\text { Establishes new } \\
\text { functionality } \\
\text { and changes or } \\
\text { has the potential } \\
\text { to change the } \\
\text { current } \\
\text { technology } \\
\text { paradigm. } \\
\text { Value is seen in } \\
\text { the eyes of } \\
\text { visionaries, not } \\
\text { necessarily the } \\
\text { mass. }\end{array}$ & $\begin{array}{l}\text { Discontinuous } \\
\text { Radical } \\
\text { Novel } \\
\text { New to the World } \\
\text { Breakthrough }\end{array}$ & Early Market \\
\hline $\begin{array}{l}\text { Technology } \\
\text { Improvement }\end{array}$ & $\begin{array}{l}\text { Change in } \\
\text { existing } \\
\text { technology that } \\
\text { significantly } \\
\text { improves } \\
\text { existing } \\
\text { functionality } \\
\text { through } \\
\text { performance, } \\
\text { quality, lowers } \\
\text { cost, or opens } \\
\text { new application } \\
\text { markets by } \\
\text { adding or } \\
\text { removing } \\
\text { features. }\end{array}$ & $\begin{array}{l}\text { Next Generation } \\
\text { New to the } \\
\text { Organization } \\
\text { New Market with } \\
\text { Retrofitted } \\
\text { Product } \\
\text { Major Revision } \\
\text { Cost reduction }\end{array}$ & $\begin{array}{l}\text { Bowling Alley } \\
\text { / Tornado }\end{array}$ \\
\hline $\begin{array}{l}\text { Technology } \\
\text { Maturity }\end{array}$ & $\begin{array}{l}\text { Change in } \\
\text { existing } \\
\text { functionality } \\
\text { moderately } \\
\text { improves } \\
\text { performance or } \\
\text { addition of new } \\
\text { features - basic } \\
\text { functionality } \\
\text { remains the } \\
\text { same }\end{array}$ & $\begin{array}{l}\text { Incremental } \\
\text { Enhancement to } \\
\text { existing product } \\
\text { line }\end{array}$ & Main Street \\
\hline
\end{tabular}

High market and technical uncertainty exists in technology invention projects that are in an early stage of market adoption. Technology improvements show lower levels of uncertainty, depending on their specific TALC stage. Technologically mature product ideas that have been widely adopted have the lowest levels of technological and market uncertainty.

\begin{tabular}{|l|c|c|c|}
\multicolumn{4}{|c}{ TABLE 5: INFLUENTIAL UNCERTAINTY FACTORS } \\
\multicolumn{1}{|c|}{$\begin{array}{c}\text { Technical } \\
\text { Uncertainty }\end{array}$} & $\begin{array}{c}\text { Market } \\
\text { Uncertainty }\end{array}$ & $\begin{array}{c}\text { Marketing } \\
\text { Adoption }\end{array}$ \\
\hline $\begin{array}{l}\text { Technology } \\
\text { Invention }\end{array}$ & High & High & Early Market \\
\hline $\begin{array}{l}\text { Technology } \\
\text { Improvement } \\
\text { (Early Majority) }\end{array}$ & Medium-High & Medium-High & Bowling Alley \\
\hline $\begin{array}{l}\text { Technology } \\
\text { Improvement } \\
\text { (Majority) }\end{array}$ & $\begin{array}{c}\text { Medium } \\
\text { Medium-Low }\end{array}$ & $\begin{array}{c}\text { Medium } \\
\text { Medium-Low }\end{array}$ & Tornado \\
\hline $\begin{array}{l}\text { Technology } \\
\text { Maturity }\end{array}$ & Low & Low & Main Street \\
\hline
\end{tabular}

\section{FRAMEWORK FOR MANAGING THE FRONT END UNDER UNCERTAINTY}

The previous sections have identified five distinctly different approaches to front-end management: linear, recursive, evolving, selectionism, and trial-and-error (see table 1). Furthermore four different types of projects were identified with different levels of market and technical uncertainty (see table 5). It has also been established that innovation uncertainty provides a connection between technology performance and market adoption. The framework is now positioned to bridge the suitable innovation projects to the FFE processes for managing levels of uncertainty as shown in table 6 .

The trial-and-error process deals with unforeseeable uncertainty and complexity through exploratory learning [9, 29] and is more suited for radical or breakthrough technology [20]. It is particularly appropriate for technology inventions with high degrees of technical uncertainty that require experimentation $[6,15,18,29]$, as well as for projects in which little or no information exist about customer requirements and preferences $[18,23]$.

\begin{tabular}{|c|c|c|c|}
\hline \multirow[b]{2}{*}{ FFE Processes } & \multirow{2}{*}{$\begin{array}{c}\text { Suitable } \\
\text { Innovation } \\
\text { Project Based } \\
\text { on } \\
\text { Performance }\end{array}$} & \multicolumn{2}{|c|}{ Uncertainties } \\
\hline & & Technical & Market \\
\hline Trial-and-Error & $\begin{array}{c}\text { Technology } \\
\text { Invention }\end{array}$ & High & High \\
\hline Recursive & $\begin{array}{l}\text { Technology } \\
\text { Improvement }\end{array}$ & $\begin{array}{l}\text { Medium- } \\
\text { High } \\
\text { Medium }\end{array}$ & $\begin{array}{l}\text { Medium-High } \\
\text { Medium }\end{array}$ \\
\hline Evolving & $\begin{array}{l}\text { Technology } \\
\text { Improvement }\end{array}$ & $\begin{array}{l}\text { Medium- } \\
\text { High } \\
\text { Medium }\end{array}$ & $\begin{array}{l}\text { Medium-High } \\
\text { Medium }\end{array}$ \\
\hline Selectionism & $\begin{array}{l}\text { Technology } \\
\text { Improvement }\end{array}$ & $\begin{array}{l}\text { Medium } \\
\text { High- } \\
\text { Medium }\end{array}$ & $\begin{array}{l}\text { High- } \\
\text { Medium } \\
\text { Medium }\end{array}$ \\
\hline Linear & Incremental & $\begin{array}{l}\text { Medium- } \\
\text { Low } \\
\text { Low }\end{array}$ & $\begin{array}{l}\text { Medium-Low } \\
\text { Low }\end{array}$ \\
\hline
\end{tabular}




\section{PICMET 2009 Proceedings, August 2-6, Portland, Oregon USA C 2009 PICMET}

Although recursive, evolving, and selectionism are different processes, they all incorporate the principle of concept testing and relying on exogenous (e.g., customer preferences and needs) or endogenous (e.g., technical alternatives) feedback [31]. As a result, each of these processes deals well with uncertainty [9, 20, 29, 31]. However, it can be argued that recursive, evolving, and selectionism processes are not at the same level of uncertainty as trial-and-error, and are generally more suitable for technology improvements for the following three reasons. First, recursive, by default is iterative and pools knowledge from multiple functional areas [9]. Through collaboration and the pooling of knowledge; reduces some of the uncertainty.

Second, evolving makes use of prototyping or simulation to solicit feedback of a concept $[10,16,26,31,32]$. Therefore, there is some level of knowledge or understanding of the technical and/or market requirements that are further derived from real-world experiences [24]. Evolving may also defer commitment to a specific technology or market need, or overdesign for multiple options until the uncertainty is resolved [15]. To defer requires some level of knowledge as to what the options are and overdesigning requires specific knowledge of each option, thereby negating some of the uncertainty.

Third, Sommer and Loch offer this rule for selectionism when the cost of the parallel tests are not cost prohibitive - if only imperfect tests exists, such as a prototype that reveals only part of the projected performance, then selectionism offers little value, it is only when qualitative information is available and when the delay cost for unknown unknowns (unk unks) to emerge would be devastating [29]. The notion of qualitative information implies knowledge of the environment, thereby negating some level of uncertainty.

The framework further refines recursive, evolving or selectionism in association with medium-high to medium uncertainty as follows. Recursive makes use of feed forward and feedback though the integration of knowledge while transforming, and interpreting internal and external information from multiple areas within the company and is therefore well suited for any combination of medium-high to medium technical or market uncertainties. Because evolving relies on exploiting concepts through prototyping and simulation in attempt to refine requirements, it is better suited to deal with uncertainty when multiple technologies are being considered by holding off the decision or overdesigning. Like recursive, evolving is well suited for any combination of medium-high or medium technical and market uncertainties. The distinguishing factor between the two is when time-tomarket is critical. Evolving provides quicker feedback from real-experiences; however, requires changes in how management supports the effort as compared to the management engine in recursive. Selectionism develops multiple to concepts and picks the best one ex-post. Since multiple concepts are developed the assumption is that some qualitative information exists. Therefore, selectionism is better suited where technical uncertainty is medium and market uncertainty is medium-high or where technical uncertainty is medium-high and market uncertainty is medium.

While recursive, evolving and selectionism are all appropriate with medium-high and medium uncertainties, the framework does not imply one is better than the other. What is implied is that when management processes demand structure, then recursive is better suited then evolving or selectionism. When time-to-market is a concern, evolving and selectionism is better suited then recursive. Under the same condition, if cost is prohibitive or only imperfect tests exist, then evolving is better suited than selectionism.

Finally, linear processes tend to encourage management processes that empathizes strategic alignment, profitability, and market awareness [20]. Therefore, a well defined business case is required and subsequently technical and market requirements are understood. Research has characterized the linear process to be more suitable for incremental improvement $[9,18,20,33]$ with medium-low to low levels of uncertainty.

\section{DISCUSSION AND CONCLUSION}

This paper has developed a theoretical framework for managing uncertainty in the front-end of product development. Based on a review of the literature, it has demonstrated that different management processes are suitable for development projects with different levels of technical and market uncertainty. This leads to position 1:

Position 1: Fuzzy Front End processes vary by the level of uncertainty for managing the innovation. Therefore, one size does not fit all and if a company has a multi faceted new development strategy that includes technology invention, improvement and extending a mature product line, then it should employ multiple front end processes to managing the portfolio of projects.

This finding is of practical relevance for companies with different kinds of development projects in their portfolios. Table 7 shows that product portfolios from the 2004 survey in general are diverse and include projects of very different nature. The survey data does not discuss the mix of project portfolios on a company level, but there are some indications that most companies do not only have one type of development project in their portfolio: Companies with explicit product strategies overwhelmingly characterize their strategy as first to market $(31 \%)$ and fast followers $(36 \%)$ which forces them to frequently develop products that are new to the world or at least to the organization[1, p27]. At the same time, all product lines need maintenance and continuous improvement. It is therefore safe to assume that the majority of all companies are forced to develop products with very different levels of uncertainty. 


\section{PICMET 2009 Proceedings, August 2-6, Portland, Oregon USA @ 2009 PICMET}

\begin{tabular}{|c|c|}
\hline Project Category & Percentage \\
\hline New to the world & $8.3 \%$ \\
\hline New to your organization & $17.5 \%$ \\
\hline Major Revision & $18.0 \%$ \\
\hline Repositioning of products & $5.4 \%$ \\
\hline Cost Reductions & $10.9 \%$ \\
\hline Additions to existing product line & $21.0 \%$ \\
\hline Incremental Improvements & $19.0 \%$ \\
\hline
\end{tabular}

Little is known if companies employ a one-size-fits-all development process for their mixed portfolio or choose from different processes. In the 2004 study, $69.1 \%$ of the companies' surveyed use a formal process with crossfunctional representation, $9.7 \%$ use a formal process that sequentially flows through each functional area, $15.1 \%$ use an informal process, and $6.2 \%$ have no NPD process [1,p17]. The study does not describe the details of the processes employed and also does not comment if the formal processes allow process variations for projects with different levels of uncertainty. Future research is needed to investigate Position 2:

Position 2: Companies that manage product development with a "one size fits all" process show lower success rates than companies with flexible development practices.

If flexible development practices in fact lead to successful uncertainty reduction, improved success should be observable in multiple ways, such as improved time to market, fewer costly reworks, and better market success due to greater knowledge of customer requirements.

The 2004 study found that $55 \%$ of the companies have a well-defined and structured portfolio management process, based on a series of decision gates. To receive funding, ideas must have a well defined business case. Discounted cash flow metrics are among the most comply used project selection criteria [1p, 28]. These practices could favor incremental projects for which it is relatively easy to provide the required information, leading to position 3 :

Position 3: A linear process with well-structured portfolio management criteria that uses financial criteria for initial gates is less likely to provide funding for technology invention or improvement projects. Companies with predominantly linear development consequently lack radical innovation.

The framework presented in this paper is based on a literature survey. To test this framework and investigate the above mentioned positions, case study research is currently underway with 4 high technology companies that produce a diverse set of innovative products and services. The research is focusing on answering the following research questions: What FFE processes are being employed by companies and for what type of innovation projects? Do the types of projects and front-end processes identified in this paper exist in practice? Do companies employ different FFE processes for different projects in their diverse portfolios? How does the application of the front-end processes identified in this paper impact project success and innovativeness?

\section{REFERENCES}

[1] M. Adams, "PDMA Foundation New Product Development Report of Initial Findings: Summary of Responses from 2004 CPAS," PDMA FoundationSeptember 2004.

[2] F. Betz, Managing Technological Innovation, Second ed. Hoboken, NJ: John Wiley \& Sons, 2003.

[3] F. D. Buggie, "SET THE "FUZZY FRONT END" IN CONCRETE," Research Technology Management, vol. 45, p. 11, 2002.

[4] J. Buijs, "Modelling Product Innovation Processes, from Linear Logic to Circular Chaos," Creativity \& Innovation Management, vol. 12, pp. 76-93, 2003.

[5] Y. Carlisle and E. McMillan, "Innovation in organizations from a complex adaptive systems perspective," Emergence: Complexity \& Organization, vol. 8, pp. 2-9, 2006.

[6] Y.-T. Cheng and A. H. van de Ven, "Learning the Innovation Journey: Order out of Chaos?," Organization Science, vol. 7, pp. 593-614, 1996.

[7] R. G. Cooper, S. J. Edgett, and E. J. Kleinschmidt, "Optimizing the Stage-Gate Process: What Best-Practice Companies Do--II," Research Technology Management, vol. 45, p. 43, 2002.

[8] R. G. Cooper and E. J. Kleinschmidt, "Stage Gate Systems for New Product Success," Marketing Management, vol. 1, pp. 20-29, 1993.

[9] M. P. E. Cunha and J. E. Comes, "Order and Disorder in Product Innovation Models," Creativity \& Innovation Management, vol. 12, p. 174, 2003.

[10] E. Dahan and H. Mendelson, "An Extreme-Value Model of Concept Testing," Management Science, vol. 47, p. 102, 2001.

[11] A. Griffin, L. N. Hoffman, R. L. Price, and B. A. Vojak;, "How Serial Innovators Navigate The Fuzzy Front End of New Product Development," Institute for the Study of Business Markets at Pennsylvania State University, 2007, pp. 1-35.

[12] A. Khurana and S. R. Rosenthal, "Integrating the Fuzzy Front End of New Product Development," Sloan Management Review, vol. 38, pp. 103-120, Winter97 1997.

[13] P. Koen, G. Ajamian, R. Burkart, A. Clamen, J. Davidson, R. D'Amore, C. Elkins, K. Herald, M. Incorvia, A. Johnson, R. Karol, R. Seibert, A. Slavejkov, and K. Wagner, "PROVIDING CLARITY AND A COMMON LANGUAGE TO THE 'FUZZY FRONT END.'," Research Technology Management, vol. 44, pp. 44-55, 2001.

[14] K. W. Koput, "A Chaotic Model of Innovative Search: Some Answers, Many Questions," Organization Science, vol. 8, pp. 528-542, 1997.

[15] V. Krishnan and S. Bhattacharya, "Technology Selection and Commitment in New Product Development: The Role of Uncertainty and Design Flexibility," Management Science, vol. 48, pp. 313-327, 2002.

[16] C. H. Loch, A. DeMeyer, and M. T. Pich, Managing the Unknown. Hoboken, N.J.: John Wiley \& Sons, 2006.

[17] C. H. Loch, C. Terwiesch, and S. Thomke, "Parallel and Sequential Testing of Design Alternatives," Management Science, vol. 47, p. 663, 2001.

[18] G. S. Lynn and A. E. Akgun, "Innovation Strategies Under Uncertainty: A Contingency Approach for New Product Development," Engineering Management Journal, vol. 10, p. 11, 1998.

[19] A. MacCormack and R. Verganti, "Managing the Sources of Uncertainty: Matching Process and Context in Software Development," Journal of Product Innovation Management, vol. 20, pp. 217-232, 2003.

[20] I. P. McCarthy, C. Tsinopoulos, P. Allen, and C. Rose-Anderssen, "New Product Development as a Complex Adaptive System of Decisions," Journal of Product Innovation Management, vol. 23, pp. 437-456, 2006.

[21] A. Merle Crawford; Di Benedetto, New Products Management, Eighth ed. New York, NY: McGraw-Hill Irwin, 2006. 


\section{PICMET 2009 Proceedings, August 2-6, Portland, Oregon USA @ 2009 PICMET}

[22] D. Z. Milosevic, Project Management ToolBox. Hoboken, NJ: John Wiley \& Sons, 2003.

[23] G. A. Moore, Crossing the Chasm. New York, N.Y.: HarperBusiness Essentials, 2002.

[24] T. Myer, "Software Development the Agile Way," Baseline, pp. 56-57, 2008.

[25] S. E. Reid and U. de Brentani, "The Fuzzy Front End of New Product Development for Discontinuous Innovations: A Theoretical Model," Journal of Product Innovation Management, vol. 21, pp. 170-184, 2004.

[26] D. G. Reinertsen, "Taking the Fuzziness Out of the Fuzzy Front End," Research Technology Management, vol. 42, p. 25, 1999.

[27] D. G. Reinertsen and P. G. Smith, "The Strategist's Role in Shortening Product Development," Journal of Business Strategy, vol. 12, p. 18, 1991.

[28] R. Sethi and Z. Iqbal, "Stage-Gate Controls, Learning Failure, and Adverse Effect on Novel New Products," Journal of Marketing, vol. 72, pp. 118-134, 2008.

[29] S. C. Sommer and C. H. Loch, "Selectionism and Learning in Projects with Complexity and Unforeseeable Uncertainty," Management Science, vol. 50, pp. 1334-1347, 2004.
[30] S. Thomke, E. von Hippel, and R. Franke, "Modes of experimentation: An innovation process--and competitive--variable," Research Policy, vol. 27, p. 315,1998

[31] S. Thomke, E. von Hippel, and R. Franke, "Modes of experimentation: an innovation process--and competitive--variable," Research Policy, vol. 27, pp. 315-332, 1998.

[32] S. H. Thomke, "The role of flexibility in the development of new products: An empirical study," Research Policy, vol. 26, pp. 105-119, 1997.

[33] B. Verworn and C. Herstatt, "Approaches to the "Fuzzy Front End" of Innovation," 1999, pp. 1-9.

[34] B. Verworn, C. Herstatt, and A. Nagahira, "The fuzzy front end of Japanese new product development projects: impact on success and differences between incremental and radical projects," $R \& D$ Management, vol. 38, pp. 1-19, 2008

[35] P. Wiefels, The Chasm Companion. New York, N.Y.: HarperBusiness, 2002.

[36] Q. Zhang and W. J. Doll, "The fuzzy front end and success of new product development: a causal model," European Journal of Innovation Management, vol. 4, pp. 95-112, 2001. 